\title{
EVALUATION OF THE RABBIT AS A MODEL FOR CHAGAS' DISEASE. I. PARASITOLOGICAL STUDIES
}

\author{
LUIZ EDUARDO RAMIREZ* \& ZIGMAN BRENER \\ Centro de Pesquisas René Rachou, FIOCRUZ, Caixa Postal, 1743, 30190 Belo Horizonte, MG, Brasil *Present \\ address: Universidad de Antioquia, Faculdad de Medicina, Medellin, Colombia
}

In order to investigate the value of the rabbit as an experimental model for Chagas' disease, 72 animals have been inoculated by intraperitoneal and conjunctival route with bloodstream forms, vector-derived metacyclic trypomastigotes and tissue culture trypomastigotes of Trypanosoma cruzi strains Y, CL and Ermane. In 95.6\% of the animals trypomastigotes had been detected at the early stages of infection by fresh blood examination. The course of parasitemia at the acute phase was strongly influenced by the parasite strain and route of inoculation. At the chronic phase parasites had been recovered by xenodiagnosis and/or hemoculture in $40 \%$ of the examined animals. The xenodiagnosis studies have shown selective interactions between the $\mathrm{T}$. cruzi strains and the four species of vectors used, inducing significant variability in the results. The data herein present are consistent with the parasitological requirements established for a suitable model for chronic Chagas' disease.

$$
\text { Key words: rabbits }-T \text {. cruzi infection - parasitological aspects - xenodiagnosis }
$$

Teixeira et al. (1975) were the first to report in rabbits experimentally infected with Trypanosoma cruzi lesions resembling pathology found in human chronic Chagas' disease. At the chronic phase the animals exhibited diffuse myocarditis, signs of heart failure and megacolon; moreover, $T$. cruzi subcellular fractions injected into normal rabbits induced myocarditis and heart cells lysis, an evidence that Chagas' disease myocardiopathy might be related to auto-immune mechanisms. In a previous paper Santos-Buch \& Teixeira (1974) have already demonstrated that lymphocytes from rabbits chronically infected with $T$. cruzi or immunized with this parasite subcellular fractions were able to lyse infected and non-infected monolayers of allogeneic rabbit heart cells. The experiments strongly suggested the existence of cross-reacting antigens between $T$. cruzi and host heart cells. Both papers raised expectations that rab. bits could be suitable models for immunopathological studies and vaccination trials in Chagas disease, allowing the identification of antigens shared by $T$. cruzi $i$ and its host cells.

More recently, further studies confirmed and expanded the in vivo observations in chronic rabbits (Teixeira et al., 1983; Figueiredo et al., 1985). However, the role of this animal as a model for chronic Chagas' disease remained controversial because these findings have not been reproduced by other groups. Thus, Andrade \& Andrade (1979) and Chiari et al. (1980) were unable to confirm those results in relation

We thank the National Research Council (CNPq), Brazil, for support.

Received April 13, 1987.

Accepted June 22, 1987 to both parasitological and pathological aspects; the parasitemia was either undetectable or negligible despite the large numbers of $T$. cruzi blood forms used in the inocula $\left(10^{4} / \mathrm{g}\right)$ and lesions were absent or not similar to those found in human chagasic cardiopathy. The reasons for the discrepancies are unclear. In this series of papers we will report our experience based on a comprehensive study of parasitological, immunological and pathological aspects of experimental Chagas' disease in rabbits.

\section{MATERIAL AND METHODS}

Rabbits - 72 outbred male rabbits 2-4 months old were used.

$T$. cruzi strains and inoculation - the following strains were used: $Y$, isolated from a chagasic acute case (Pereira da Silva \& Nussenzweig, 1953); CL, isolated from a naturally infected Triatoma infestans collected in Rio Grande do Sul, South Brasil (Brener \& Chiari, 1963) and Ernane (isolated from a chagasic patient with cardiac form and megaesophagus). The infective stages were blood trypomastigotes obtained from experimentally infected mice (BTry) inoculated with the $Y, C L$ and Ernane strains and bled at the 7th, 12th and 30th days of infection, respectivelly; tissue-culture derived trypomastigotes (TcTry) yielded by "Vero" cells infected with the Y strain; finally, metacyclic trypomastigotes (MTry) obtained from triatomid bugs (Dipetalogaster maximus) fed on mice inoculated with Y, CL and Ernane strains.

The following groups of animals were studied: 14,16 and 12 rabbits inoculated by intraperitoneal route (i.p.) with $10^{7}$ BTry of, respectivelly, Y, CL and Ernane strains; three 
groups of 8 rabbits inoculated with $2-4 \times 10^{3}$ MTry of, respectivelly, Y, CL and Ernane strains, by conjunctival route; finally, 6 rabbits with $10^{7}$ TcTry by i.p. route.

Parasitological examination - Fresh blood examination was daily performed after inoculation by collecting $5 \mu \mathrm{l}$ of blood from the rabbit ear and counting the number of parasites according to Brener (1962). Xenodiagnosis was carried out at different periods after inoculation using lst stage nymphs of Dipetalogaster maximus and 3rd stage nymphs of Triatoma infestans, Rhodnius neglectus and Panstrogylus megistus. Two boxes with 10 nymphs each were used and the insects kept at $26-28^{\circ} \mathrm{C}$ examined after 30-40 days. In a number of animals in the chronic phase hemoculture was performed to detect ongoing $T$. cruzi active infections. The animals were bled through the marginal ear vein and $10 \mathrm{ml}$ of heparinized blood collected asseptically. The blood was then centrifuged at 2,000 r.p.m for $30 \mathrm{~min}$ and the cell pellet washed with LIT ("liver-infusion tryptose") medium and then inoculated into three tubes with $6 \mathrm{ml} \mathrm{LIT}$. The cultures were kept at $28^{\circ} \mathrm{C}$ and then examined after 30 and 60 days for living flagellates.

\section{RISULTS}

From the 68 rabbits examined during the acute phase, $65(95.6 \%)$ showed positive fresh blood examination; in the group of the three remaining animals, one had parasites detected by xenodiagnosis and in the other two an indirect immunofluorescence test using $T$. cruzi epimastigote stages as antigen was positive at low titres ( $1: 20)$, but fresh blood examination and xenodiagnosis remained negative. Some characteristics of the acute phase such as pre-patent period and curves of parasitemia were strongly influenced by the parasite strain. the infective stages used as inocula and the inoculation route, as illustrated by the following data.

Figs. 1 and 2 show the curves of parasitemia in rabbits inoculated with BTry and MTry of $T$. cruzi $Y$ strain by, respectivelly, i.p. and conjunctival route. In the first group of animals, inoculated with BTry the parasitemia was rather low and of short duration ( 5 to 11 days): in the animals inoculated with the vector-derived trypomastigotes the pre-patent period was significantly delayed, the prarasitemia very low and of short duration as well. Figs. 3 and 4 display curves of parasitemia of rabbits inoculated with the CL strain. In two animals inoculated with the BTry by i.p. parasites were detected as soon as $24 \mathrm{~h}$ after infection, surely corresponding to infective stages of the inocula which almost di- rectly pass to the bloodstream; parasitemia gradually increased to subside within 3 weeks infection; in one animal an abortive infection was induced. In the rabbits inoculated with the MTry by conjunctival route the pre-patente period was unusually long ( 23 to 33 days), the parasitemia significantly lower than that of the previous group inoculated with the BTry, and the patent period was of variable duration. Fig. 5 shows parasitemia curves in animals inoculated with MTry of T. cruzi Ernane strain by conjunctival route. The pre-patent period was of about 2-weeks, the curves of parasitemia were irregular and parasites remained circulating for $3-4$ weeks. Finally, in the rabbits inoculated with TcTry by i.p. route, BTry were extremely scarce in the bloodstream and circulate for only a few days (data not shown).

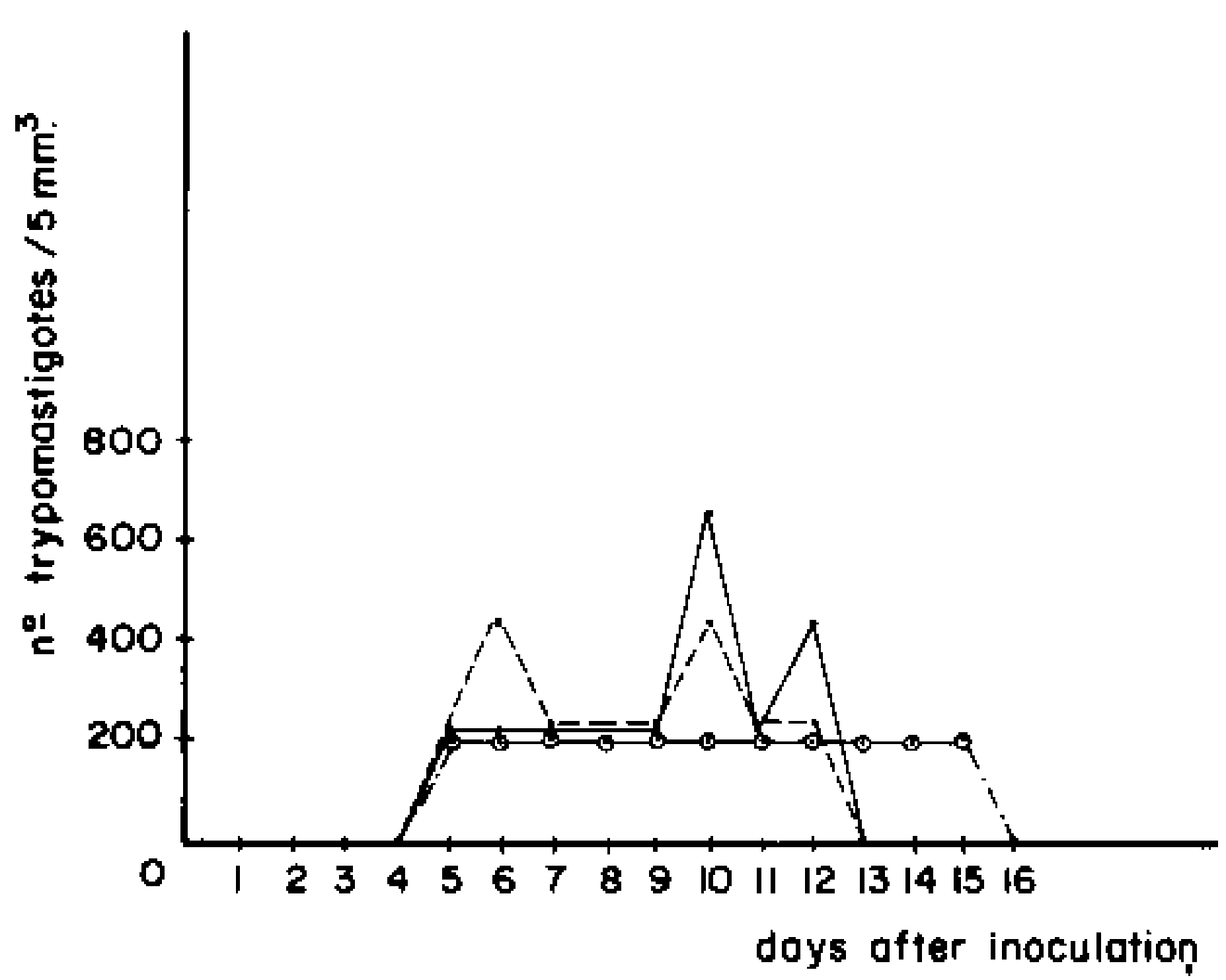

1.ig. 1 : Curves of parasitemia in rabbits inoculated with $10^{7}$ bloodstream forms of $T$. cruzi Y strain, by intraperitoneal toute.

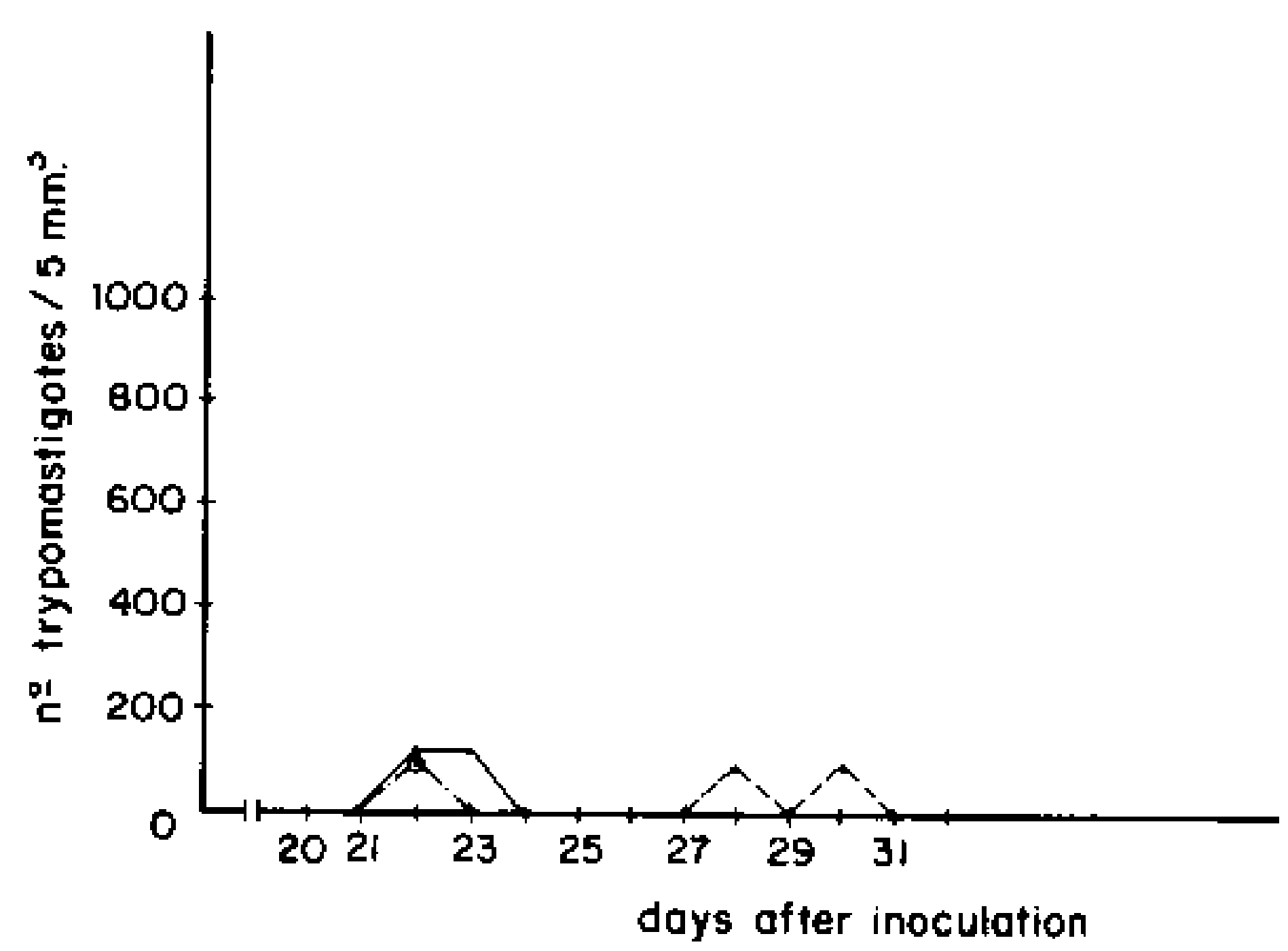

Fig. 2: Curves of parasitemia in rabbits inoculated with $2-4 \times 10^{3}$ metacyclic trypomastigotes collected from Dipetalogaster maximus infected with $T$. cruzi $\mathrm{Y}$ strain, by conjunctival route. 


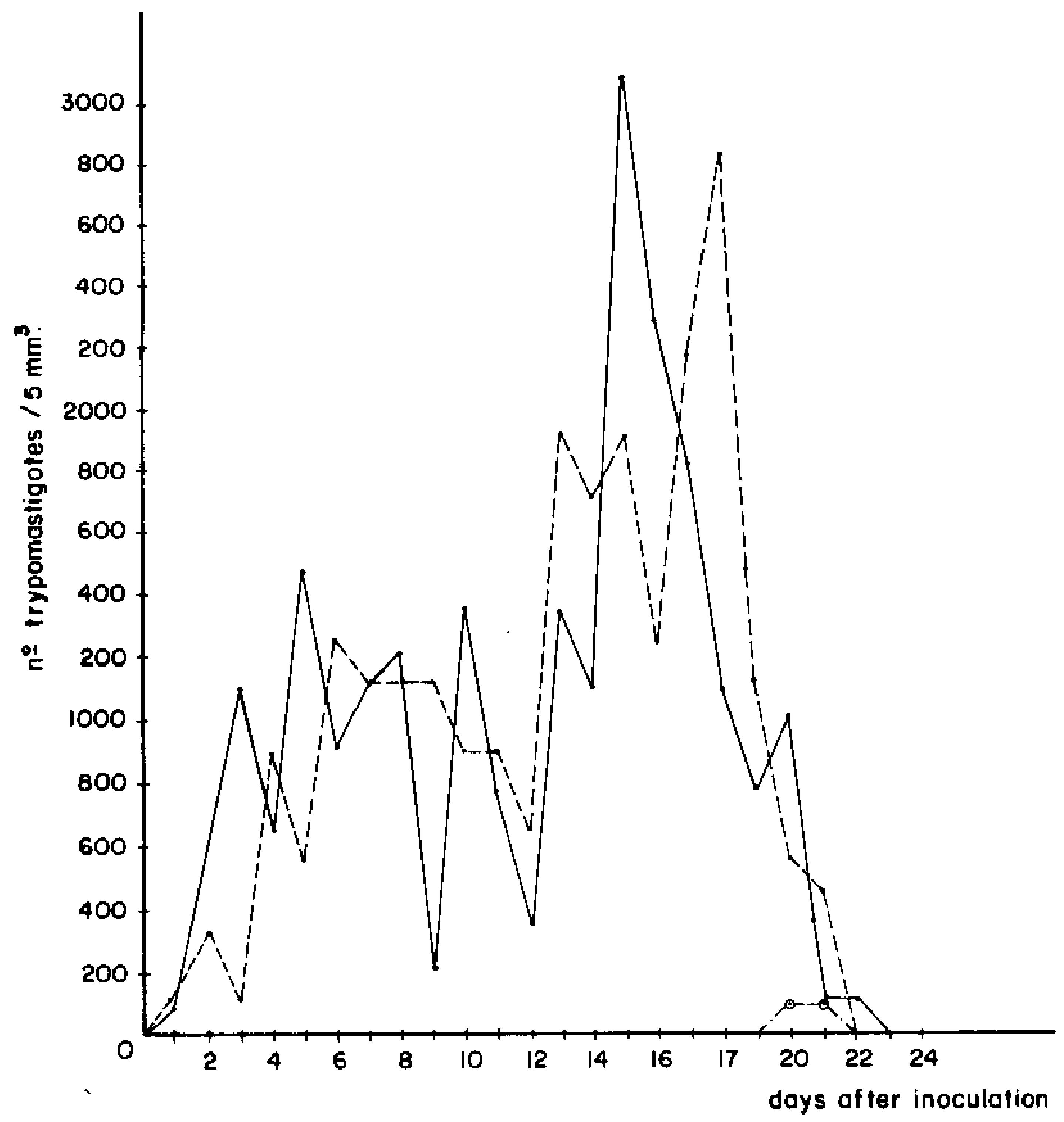

Fig. 3: Curves of parasitemia in rabbits inoculated with $10^{7}$ bloodstream forms of $T$. cruzi CL strain, by intraperitoneal route.

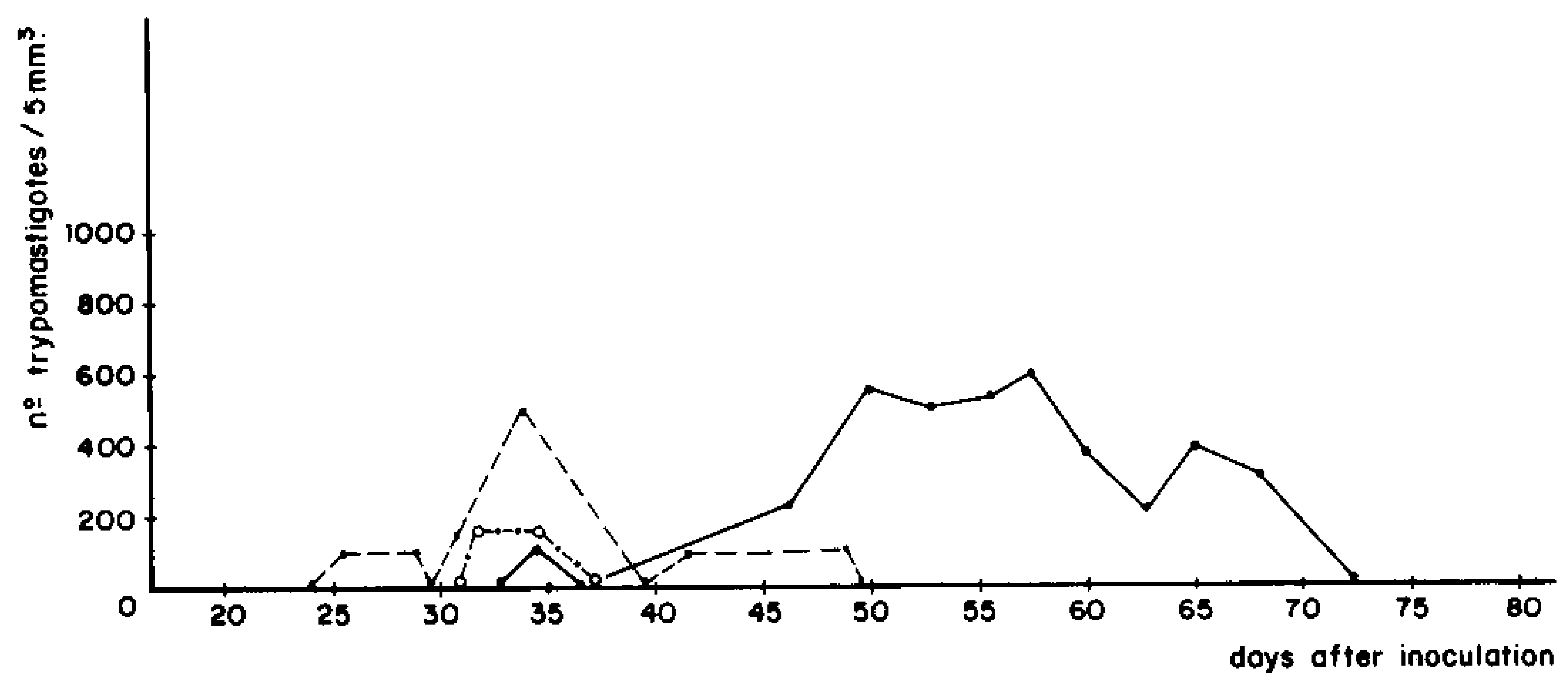

Fig. 4: Curves of parasitemia in rabbits inoculated with $2-4 \times 10^{3}$ metacyclic trypomastigotes from Dipetalogaster maximus infected with $T$. cruzi CL strain, by conjunctival route. 


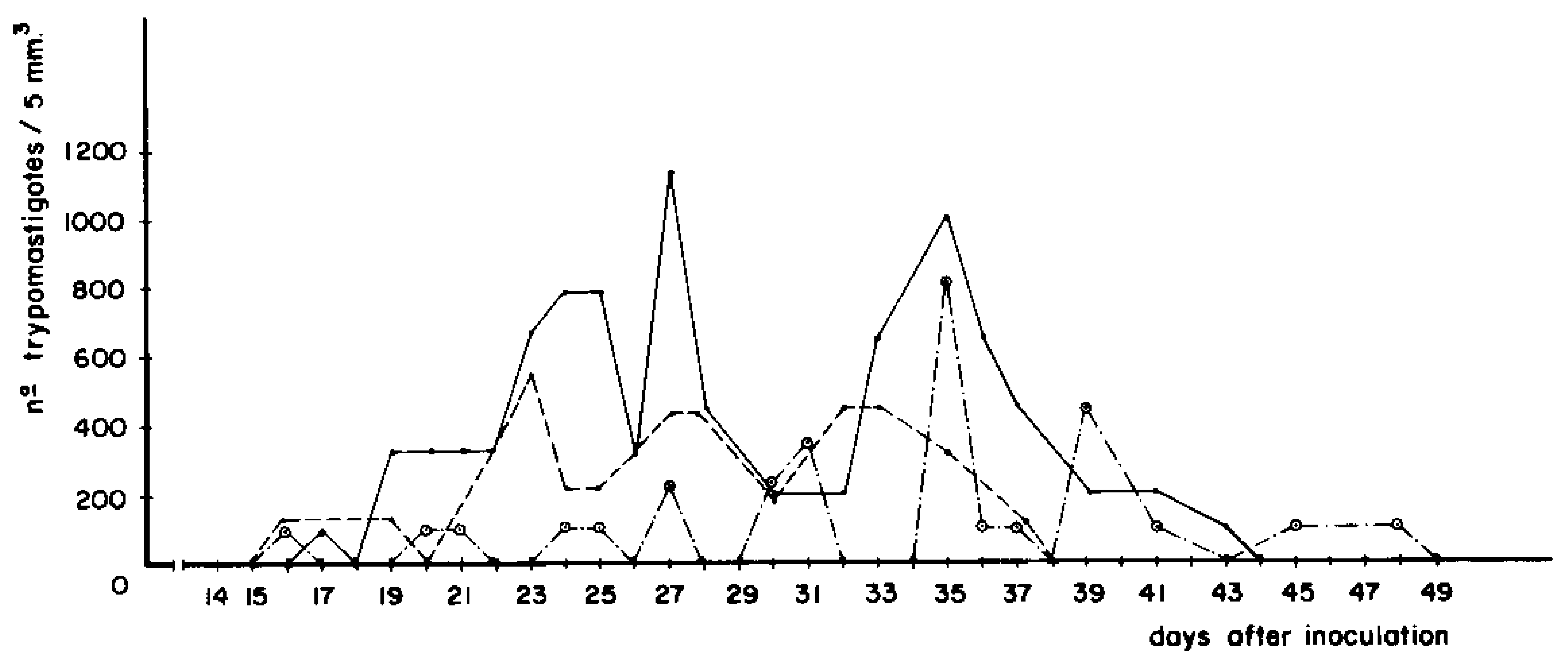

Fig. 5: Curves of parasitemia in rabbits inoculated with $2-4 \times 10^{3}$ metacyclic trypomastigotes from Dipetalogaster maximus infected with $T$. cruzi Ernane strain, by conjuctival route.

Table I shows the percentage of positive xenodiagnosis in 36 rabbits inoculated with $Y$ and CL T. cruzi strains, examined for a period of 3 to 22 months after inoculation. The percentage of positive xenodiagnosis was significantly higher in the group of animals inoculated with $C L$ than with,$Y$ strain. An interesting peculiarity was that a higher percentage of positive xenodiagnosis was detected in the group of animals inoculated by i.p. route (CL: $75 \%$, Ernane: $50 \%$ and $\mathrm{Y}: 20 \%$ ) than in those inoculated by conjunctival route (CL: $33 \%$, Ernane: $25 \%$ and Y: $12 \%$ ). In Table II are shown the results obtained using four different vector species in the xenodiagnosis performed in rabbits inoculated with the same both strains and also followed-up for 3 to 22 months. In relation to the animals inoculated with the Ernane strain the xenodiagnosis had been carried out only for the period of 2 to 10 months after inoculation and in 5 out of 14 rabbits $(35.7 \%)$ parasites could be detected after examination of 108 tests. In summary, from a total of 50 rabbits inoculated with the three $T$. cruzi strains and submitted to 536 xenodiagnosis using four different vector species, 19 animals $(38.0 \%)$ were positive. Finally, Table III displays results of hemoculture performed in rabbits inoculated with $\mathrm{Y}$ and $\mathrm{CL}$ strains and bled at the chronic phase $(7-24$ months after inoculation), showing again a sig. nificantly higher percentage of positive results in the animals inoculated with the CL strain. Since one of the rabbits presenting positive hemoculture had negative xenodiagnosis, the total number of animals in which parasites could be detected by either method was 20 out of 50 examined $(40 \%)$.

\section{DISCUSSION}

In recent papers related to the use of the rabbit as a model for Chagas' disease studies, parasitemia has been ascertained either by positive xenodiagnosis (Teixeira et al., 1983; Figueiredo et al., 1985) or was often undetectable (Andrade \& Andrade, 1979; Chiari et al., 1980). In our material $95.6 \%$ of the inoculated rabbits exhibited a typical acute phase as defined by the presence of patent parasitemia demonstrated by fresh blood examination. In some occasions when huge inocula of BTry of the CL strain were given by i.p. route, the prepatente period was difficult to esblish because a certain percentage of the parasites were able to pass directly into the bloodstream could be detected as early as 24 hours after inoculation. In general this early parasitemia merged with the subsequent waves of parasites which resuled from the intracellular cycle, characterizing the acute phase. This phenomenon has been reported by Dias (1934) and again investigated by Brener (1969). On the other hand, in the animals inoculated by conjunctival route with MTry the pre-patente period, whatever the strain used, was fairly long ( 2 to 4 weeks).

In accordance with data obtained in other experimental $T$. cruzi hosts such as mice and dogs (Brener, 1977; Pedreira de Castro \& Brener, 1985) the curves of parasitemia in rabbits have been strongly influenced by the $T$. cruzi strain used as inoculum and the route of infection. In general animals inoculated with the $\mathrm{CL}$ strain exhibited higher and more prolonged parasitemia than those induced by $Y$ strain. This phenomenon is likely to depend on strain-rela- 
TABLE I

Percentage of positive xenodiagnosis in rabbits inoculated with the $\mathrm{Y}$ and CLT cruzi strains and followed-up for 3 to 22 months after inoculation

\begin{tabular}{lcccc}
\hline $\begin{array}{c}\text { T. cruzi } \\
\text { strain }\end{array}$ & No. animals & No. tests & $\begin{array}{c}\text { No. positive } \\
\text { animals }\end{array}$ & $\begin{array}{c}\text { \% positive } \\
\text { animals }\end{array}$ \\
\hline Y & 18 & 211 & 3 & 16.7 \\
CL & 18 & 217 & 11 & 61.1 \\
\hline
\end{tabular}

TABLL II

Results of xenodiagnosis in rabbits inoculated with the Y and CL T. cruzi strains, performed within the period of 3 to 22 months using four different triatomid-bugs species

\begin{tabular}{lccccc}
\hline \multicolumn{1}{c}{ Vector } & $\begin{array}{c}\text { T. cruzi } \\
\text { strain }\end{array}$ & No. animals & No. tests & $\begin{array}{c}\text { No. positive } \\
\text { animals }\end{array}$ & $\begin{array}{c}\% \text { positive } \\
\text { animals }\end{array}$ \\
\hline Rhodnius neglectus & $\mathrm{Y}$ & 18 & 90 & 0 & 0 \\
Triatoma infestans & $\mathrm{Y}$ & 14 & 43 & 1 & 7.1 \\
Panstrongylus megistus & $\mathrm{Y}$ & 12 & 39 & 2 & 16.6 \\
Dipetalogaster maximus & $\mathrm{Y}$ & 12 & 39 & 2 & 16.6 \\
Rhodnitus neglectus & $\mathrm{CL}$ & 18 & 140 & 11 & 61.1 \\
Triatoma infestans & $\mathrm{CL}$ & 17 & 43 & 1 & 5.8 \\
Panstrongystus megistus & $\mathrm{CL}$ & 9 & 17 & 0 & 0.0 \\
Dipetalogaster maximus & $\mathrm{CL}$ & 9 & 17 & 1 & 11.1 \\
\hline
\end{tabular}

TABLE: III

Percentage of positive hemocultures in rabbits inoculated with the $\mathrm{Y}$ and CL T. cruzi strains and examined at the chronic stage of infection ( 7 to 22 months) after inoculation

\begin{tabular}{ccccc}
\hline $\begin{array}{c}T \text { cruzi } \\
\text { strain }\end{array}$ & No. animals & No. tests & $\begin{array}{c}\text { No. positive } \\
\text { animals }\end{array}$ & $\begin{array}{c}\% \text { positive } \\
\text { animals }\end{array}$ \\
\hline $\mathrm{Y}$ & 11 & 15 & 0 & 0 \\
$\mathrm{CL}$ & 16 & 23 & 4 & 25.0 \\
\hline
\end{tabular}

ted biological differences of the BTry of both populations. There is a bulk of evidence showing that BTry from the CL strain are better equipped than the $\mathrm{Y}$ strain to evade both in vivo and in vitro from the effects of anti-T. cruzi an. tibodies (Krettli \& Brener, 1976). Moreover, as demonstrated by Bertelli \& Brener (1980), CL BTry collected from mice at 12 - 14 days of infection display limited capacity to invade muscle and epithelial cells, a phenomenon that to. gether with the resistance of these forms to the immune response might result in a gradual accumulation of the parasites in the host bloodstream (reviewed by Brener, 1980).
A suitable chronic model for Chagas' disease should allow the recovery of the parasites at the late infection by conventional parasitological methods. This aspect has been also investigated in our inoculated rabbits at the chronic phase when BTry could not anylonger be detected by fresh blood examination. In general, parasites could be recovered by xenodiagnosis and/or hemoculture in $40 \%$ of the examined animals, a figure consistent with the above mentioned requirement. In addition, as we will show in the next paper of this series, there is enough evidence provided by serological meth- 
ods showing that pratically all inoculated rabbits remained infected by $T$. cruzi.

Our experience with xenodiagnosis disclosed interesting aspects of the interaction between $T$. cruzi $i$ and its vectors, namely, the impressive susceptibility of $R$. neglectus to infection by the CL strain (61.1\% positive) and the refractoriness to the $Y$ strain ( $0 \%$ positive). These differences are not likely to be explained by the higher parasitemia observed at the early stages of the infection induced by CL strain. Actually, the xenodiagnosis had been performed every two months for 3 to 22 months after infection and the higher percentage of positive xenodiag. nosis in the CL-inoculated rabbits was present during the whole period of observation (data not shown). Interestingly, the same facility to detect parasites in rabbits inoculated with the CL strain rather than with the Y strain was observed when hemoculture was used instead.

\section{RESUMO}

Avaliação do coelho como modelo para a doença de Chagas. I. Estudos parasitológicos - Com a finalidade de investigar o uso do coelho como modelo experimental da doença de Chagas, 72 desses animais foram inoculados por via intraperitoneal e conjuntival com formas sanguíneas, tripomastigotas metacíclicos obtidos de triatomíneos e tripomastigotas obtidos de cultura de tecido, usando-se as cepas $Y$, CL e Ernane do T. cruzi. Em $95,6 \%$ dos coelhos o exame de sangue a fresco foi positivo, o que evidencia uma alta suscetibilidade desses animais à injecção pelo $T$. cruzi. $\mathrm{O}$ curso da parasistemia na fase aguda da infecção é intensamente influenciado pela cepa do parasita e via de inoculação usada. Na fase crônica parasitas foram recuperados através de xenodiagnóstico e/ou hemocultura em $40 \%$ dos coelhos examinados. A análise dos resultados dos xenodiag. nósticos revelou a existència de interações seletivas entre as cepas do $T$. cruzi e as quatro espécies de vetores empregados, evidenciadas por significativa variabilidade dos resultados. De um modo geral os resultados obtidos no presente trabalho atendem ao pre-requisito de ordem parasitológica sugerido para um modelo para a doença de Chagas na fase crônica.

Palavras-chave: coelhos - infecção por $T$. cruzi aspectos parasitológicos - xenodiagnóstico
REFERENCES

ANDR ADE, Z.A. \& ANDRADE, S.G., 1979. Patologia p. 199-248. In: Z. Brener \& Z. Andrade, Trypano. some cruzi e Doença de Chagas. Editora Guanabara Koogan, Rio de Janeiro.

BERTELLI, M.S. \& BRENER, Z., 1980. Infection of tissue culture cells with bloodstream trypomastigotes of Trypanosoma cruzi. J. Parasitol., 66 :992-997.

BRENER, Z., 1962. Therapeutic activity and criterion of cure on mice experimentally infected with Trypanosoma cruzi. Rev. Inst. Med. trop. Sāo Paulo, 4 :389-396.

BRENER, Z., 1969. The behaviour of slender and stout forms of Trypanosoma cruzi in the bloodstream of normal and immune mice. Ann. Trop. Med. Parasitol., $63: 215 \cdot 220$.

BRENER, Z., 1977. Intraspecific variation in Trypanosoma cruzi: two types of parasite populations presenting distinct characteristics. Pan American Health Organization, Scientific Publication, No. $347: 11-21$

BRENER, Z., 1980. Immunity to Trypanosoma cruzi. Adv. Parasitol, $18: 247-292$.

BRENER, Z. \& CHIARI, E., 1963. Variações morfológicas observadas em diferentes amostras do Trypanosoma cruzi. Rev. Inst. Med. trop. Säo Paulo, 5 $: 220-224$,

CHIARI, E.; TAFURI, W.L.; BAMBIRRA, E.A.; REZENDE, M.M.; RIBEIRO, T.O.; CASTRO, L.P.; SALGADO, J.A. \& AMARAL DE PADUA, R.A., 1980. The rabbit as a laboratory animal for studies on Chagas' disease. Rev. Inst. Med. trop. Säo Paulo, $22: 207-208$.

DIAS, E., 1934. Fstudos sobre o Schizotrypanum cruzi, 1934. Mem. Inst. Oswaldo Cruz, $28: 1-110$.

FIGUEIREDO, F.; ROSSI, M.A. \& SANTOS, R.R., 1985. Evolução da cardiopatia experimentalmente induzida em coelhos infectados com Trypanosoma cruzi. Rev. Soc. Bras. Med. Trop., 18 :133-141.

KRETTLI, A.U. \& BRENER, Z., 1976. Protective effects of specific antibodies in Trypanosoma cruzi infections. J. Immunol, $116: 755.760$.

PEDREIRA DE CASTRO, M.A. \& BRENER, Z., 1985. Estudo parasitológico e anátomo-patológico da fase aguda da doença de Chagas em cäes inoculados com duas diferentes cepas do Trypanosoma cruzi Rev. Soc. Bras. Med. Trop., 18 :223-229.

PEREIRA DA SILVA, L.H. \& NUSSENZWEIG, V., 1953. Sobre uma cepa de Trypanosoma cruzi altamente virulenta para o camundongo branco. Fo. lia Clin. Biol., $20: 191-208$.

SANTOS-BUCH, C.A. \& TEIXEIRA, A.R.L., 1974. The immunology of experimental Chagas' disease. III. Rejection of allogeneic heart cells in vitro. $J$. Exp. Med., $140: 83-93$.

TEIXEIRA, A.R.L.; TEIXEIRA, M.G.L.C. \& SANTOS -BUCH, C.A., 1975. The immunology of experimental Chagas' disease. IV Production of lesions in rabbits similar to those of chronic Chagas' disease in man. Am. J. Pathol, $80: 163-180$.

TEIXEIRA, A.R.L.; FIGUEIREDO, F.; REZENDE FILHO, J. \& MACEDO, V., 1983. Chagas' disease. A clinical, parasitological, immunological and pathological study in rabbits. Am. J. Trop. Med. Hyg., $32: 258.272$. 